\title{
Influence of Education on the Socio-Cultural and Economic Development among the Manobo of Cotabato, Philippines
}

\author{
Beatriz De Villa-Gosadan Ed.D ${ }^{1 *}$, Bro. Arul Rayan, Ph.D., Fsg ${ }^{2}$ \\ ${ }^{1}$ Professor, Graduate school and College of Education Central Mindanao Colleges, Kidapawan City, \\ Philippines \\ ${ }^{2}$ School Director- Montfort Academy, Romblon, Romblon, Philippines Lecturer-Aklan Catholic College, Aklan, \\ Philippines
}

*Corresponding Author: Beatriz De Villa-Gosadan, Professor, Graduate School and College of Education Central Mindanao Colleges, Kidapawan City, Philippines

\begin{abstract}
The education of the Manobo in the Philippines is elusive. They have always aspired, dreamed and desired to be educated to improve their status in the society and uplift their standards of living. This descriptive-correlational study was conducted among 106 respondents, conveniently chosen by the researchers based on their accessibility in the different Manobo dominated areas in Cotabato Province. The data were gathered through survey questionnaires. The results of descriptive analysis revealed a moderate level of illiteracy among the Manobo that subsequently, deprived them the chance to know themselves and be open to ideas that will contribute to their personal and collective improvement. Access of the Manobo to the Alternative Learning System and scholarships has helped them adopt the proper health practices and improve their literacy. As farmers, they still lack the skills of advance farming method that pushed them to sell portions of their lands. Further, this study also disclosed significant relationships between education and sociocultural development factors. In addition, education had positive significant relationship with economic development factors in terms of family income, house hold material possessions, cars and farm animals. This study concluded that the basic community services like health, education and others were already enjoyed by the respondents that also gradually replaced their cultural system. There were evidences of positive influence of education on the socio-cultural and economic development among the Manobo which helped them to improve their standards of living.
\end{abstract}

Keywords: Indigenous education, Socio-cultural development, Economic development, Philippines

\section{INTRODUCTION}

Education, like development has an arguable relationship with the Indigenous People. While education has allowed some members of the tribe to cross boundaries of culture and politics, it has also taken away their self-confidence and dishonored the local knowledge among the members of the ethnic groups (Gonos, 2012). Education is seen by many as a necessary component of the Manobos' assertion for self- determination (Alejo, 2012). Marginalized groups, including indigenous peoples, face multiple barriers to education and are being left behind in terms of educational achievement. Developing tailored, culturally and linguistically appropriate educational programs for indigenous learners were not a priority (United Nations Human Rights, 2014).

The Manobo is one of the fifteen Lumad - ethnic highlanders or indigenous peoples that are longing for recognition in the society. Their being located in the distant mountain ranges of Agusan and Cotabato make them less accessible to development. Promotion of their welfare is not sincerely pursued. Their standard of living is low as compared with the lowlanders (Peralta, 2013). Securing good job or employment and political involvement are prioritized to educationally qualified individuals (Elevaso, 2015). The Manobo people have always aspired, dreamed and desired to be educated. They view education as an important tool to improve their life conditions by pursuing economic, social and cultural development (Masendo, 2015).The Manobo realized that there will be greater opportunities for them if they are educated. To them, educating themselves will concomitantly reduce their illiteracy and increase their individual productivity (Abujuela, 2012). 
In 2007, a conference of Asia indigenous People's Pact (AIPP) in Pokhara, Nepal was held and discussed the concerns about education of the IPs and recommended that customary laws of indigenous peoples in Asia should also be formalized and documented for the preservation of their culture. In the Philippines, DepEd Order Number 62, s.2011 known as National Indigenous Peoples Educational Framework stated that documentation and research activities by Indigenous People (IP) on their own history, knowledge, practices and other aspects of cultural heritage shall be encouraged and supported by the Department of Education and other agencies as a means of enriching the learning resources available to IP communities and the educational system at large (Department of Education, 2011).

After a thorough review on related literature, the researchers noted only a limited number of related studies dealing on Indigenous Peoples and most importantly they were not able to come across a study about the Obo, Manobo of Cotabato Province. Moreover, the National Council for indigenous People (NCIP) Cotabato Provincial Office has a scarcity of data related to this investigation. Very importantly, one of the authors of this paper is a member of the Manobo Indigenous Tribe and an educator realized the need to conduct study. In addition, this study also aimed to inspire every Manobo learner to take education seriously and get a college degree as it could be their way out of poverty. Moreover, this study determined to find out the level of education and its relationship with socio-cultural and socio-economic development of Manobo community.

\section{OBJECTIVES OF ThIS STUdY}

1) To determine the respondents' level of education

2) To measure the level of their socio-cultural and economic development.

3) To determine the relationship between education and the practices of the Manobo on their social, cultural and economic development.

\section{Theoretical And Conceptual Framework OF The Study}

The guiding premise of this study was Vygotsky's sociocultural theory of human learning which describes learning as a social process and the origination of human intelligence in society or culture. Vygotsky's theory stresses the fundamental role of social interaction in the development of cognition (Vygotsky, 1978), as he believed strongly that community plays a central role in the process of "making meaning."

McLeod (2014) noted that according to Vygotsky, cognitive development stems from social interactions from guided learning within the zone of proximal development as children and their partner's co-construct knowledge. He also sees cognitive functions, even those carried out alone, as affected by the beliefs, values, and tools of intellectual adaptation of the culture in which a person develops and therefore socio-culturally determined. The tools of intellectual adaptation, therefore, vary from culture to culture.

This study is also of great importance for the promotion of the Indigenous People's Welfare as mandated in the 1987 Constitution of the Philippines, Article XIV Section 22 which reiterates the recognition, respect and protection of the rights of indigenous people to preserve their culture, traditions and institutions. To add, Chapter IV, Section 30 of the Indigenous Peoples Rights Act (1997) indicates that the state shall provide equal access to cultural opportunities to the Indigenous People through the educational system, public or private cultural entities, scholarship grants and other incentives without prejudice to their right to establish and control their own educational systems and institutions (Abayao, 2014).

The purpose of this research is to determine the influence of education on the socio-cultural and economic development among the Manobo of Cotabato. Further, it is conceptualized that education will effect change on the socio-cultural and economic development among the Manobo of Cotabato, Philippines. 


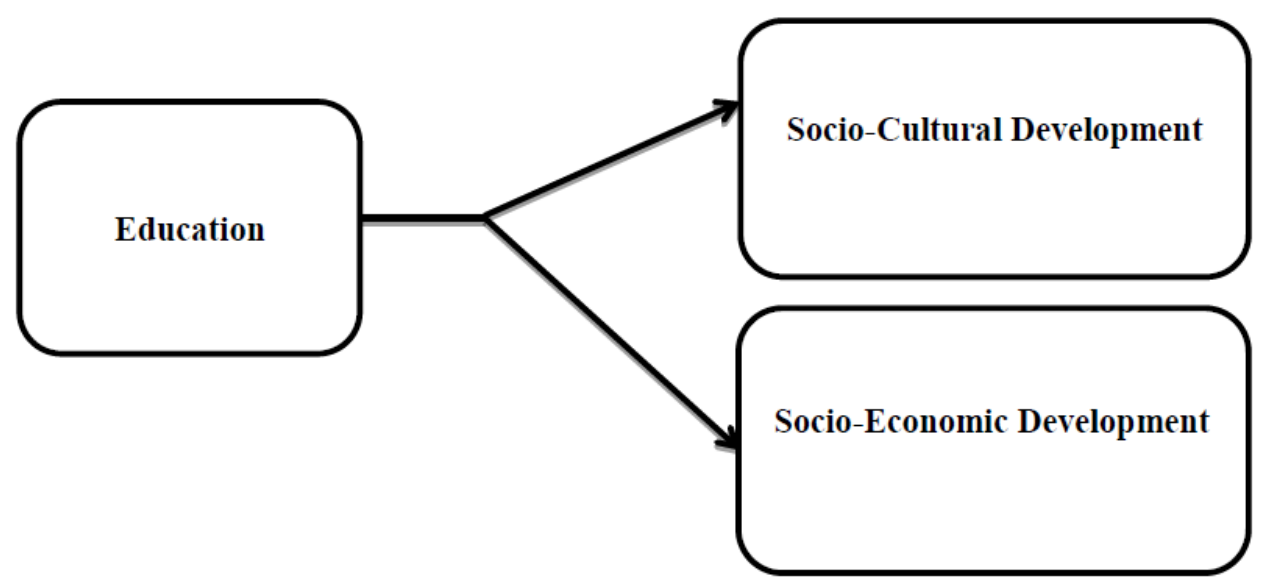

Fig1. Paradigm of the study

On the socio-cultural aspects, education is presumed to effect change on their leadership, community participation and health practices, Community Involvement, Tending Sick, Sanitation, Garbage disposal, Child care, and Immune System,. On the economic aspect, education is presumed to effect change on their family income, employment, years employed, household material possessions, land holdings, cars, and farm animals.

\section{REVIEW OF Literature}

\subsection{Indigenous Peoples in the Philippines}

According to United Nations Development program report(2010), the Philippines is a culturally diverse country with an estimated 14- 17 million Indigenous Peoples (IPs) belonging to 110 ethnolinguistic groups; they are mainly concentrated in Northern Luzon (Cordillera Administrative Region, $33 \%$ ) and Mindanao (61\%), with some groups in the Visayas area. The Philippine Constitution, in recognition of this diversity and under the framework of national unity and development, mandates state recognition, protection, promotion, and fulfillment of the rights of Indigenous Peoples. Further, Republic Act 8371, also known as the "Indigenous Peoples Rights Act" (1997, IPRA), recognized the right of IPs to manage their ancestral domains and has become the cornerstone of current national policy on IPs.

Wherever Indigenous Peoples live, they remain among the poorest and most disadvantaged peoples. The first-ever Report on the State of the World of Indigenous Peoples, issued by the United Nations Permanent Forum on Indigenous Issues in January 2010, revealed that IPs make up fully one-third of the world's poorest peoples, suffer disproportionately in areas like health, education, and human rights, and regularly face systemic discrimination and exclusion. In the Philippines, IPs have been subject to historical discrimination and marginalization from political processes and economic benefit. They often face exclusion, loss of ancestral lands, displacement, pressures to and destruction of traditional ways of life and practices, and loss of identity and culture example. Among the prominent groups are the Badjao, B'laan, Bagobo, Mangyan, Manobo, T'boli, and Teduray.

According to Mattias Lentz, the deputy head of the EU delegation to the Philippines, "The indigenous peoples in the Philippines also face many challenges in the context of development, peace and security, and human rights, most notably in Mindanao...where the overall socio-economic indicators are some of the lowest in the country and where there has been long-standing armed conflict," (ABSCBN, 2015)

\subsection{Manobo}

Manobo simply means "people" or "person"; alternate names include Manuvu and Minuvu. The term may have originated from "Mansuba," a combination of man (people) and suba (river). Manobos are concentrated in Agusan, Bukidnon, Cotabato, Davao, Misamis Oriental, and Surigao Del Sur.

The Manobo usually build their villages near small bodies of water or forest clearings, although they also opt for hillsides, rivers, valleys, and plateaus. The communities are small, consisting of only 4-12 houses. They practice slash-and-burn agriculture. 
The Ubo are a Manobo sub-tribe who inhabit the more isolated mountains of Southwest Cotabato in the area known as DatalTabayong, as well as, more southerly Davao del Sur. As of last count, they numbered close to 17,000 (OSCC, 1987); a follow up on their numbers in subsequent years has proved difficult.

Known for their intricate casting, the Ubo fashion fine weaponry and jewelry that they believe possess souls, making it harder for the maker to part with them. Agriculturally, they practice swidden, a slashand-burn farming, oft planting and harvesting rice, root crops, and vegetables for consumption. Like the Bagobo, the Ubo believe in multiple deities headed by a central figure, Diwata (God); they're animist, they also believe in ancestral spirits and unseen beings inhabiting the animate and inanimate objects found throughout their environment. In civic matters, the political leader and Datu (Filipino chieftain) of the village attains his position by virtue of wealth; speaking ability and knowledge of customary law, known as fendan. The primary obligation consists of settling disputes among members of a family, neighbors, and the community. When a fine is set and/or imposed by the Datu, the accused has to pay it to the aggrieved party; if he's unable to, then he will become servant to the one who pays for him, otherwise known as dok.

\subsection{Education and Indigenous Peoples}

According to Amnesty International, there are 370 million indigenous peoples in the world that are clustered to 5000 various groups. Seventy percent are in Asia. In the Philippines, indigenous peoples make up an estimated 17 million of the country's population. According to the United Nations report majority of these peoples are situated in Northern Luzon and in Mindanao and some spread out in Visayas.

Although a concrete and universal definition of "indigenous" is uncertain, there is an understanding that indigenous people differ from the dominant groups in society in that they possess "a historical continuity with pre-invasion and pre-colonial societies that developed on their territories4)". They have a distinctive social, economic, and political system and carry with them a firmness to preserve their culture and conserve their ancestral environments. However, indigenous peoples face multifarious problems. They are often displaced from their lands, are relegated as second-class members of society, and are alienated from the spread of capitalism. These unpleasant realities continue to exist. These distressing actualities can be majorly attributed to the deprivation of access to quality education for indigenous communities.

As the government overhauled the education system to adhere to international standards that are perpetuated by ASEAN, the Department of Education (DepEd) adopted the Indigenous Peoples Education Curriculum Framework which enunciates "guidance to schools and other education programs as they engage with indigenous communities in contextualizing the $\mathrm{K}$ to 12 Curriculum" (Republic of the Philippines Department of Education, 2015, para. 1). This DepEd order, which is the result of numerous consultations with elders, leaders, and initiators of community-based indigenous learning, recognizes the right that indigenous peoples have for a culturally sensitive and responsive education. This will serve more than a million indigenous students in public schools and in community and civil society organization-managed schools.

\subsection{Education and Development}

Education is extremely important for indigenous children, youth and adults. As the Expert Mechanism on the Rights of Indigenous Peoples (EMRIP) points out: "Education of indigenous children contributes to both individual and community development, as well as to participation in society in its broadest sense. Education enables indigenous children to exercise and enjoy economic, social and cultural rights, and strengthens their ability to exercise civil rights in order to influence political policy processes for improved protection of human rights. The implementation of indigenous peoples' right to education is an essential means of achieving individual empowerment and self-determination. Education is also an important means for the enjoyment, maintenance and respect of indigenous cultures, languages, traditions and traditional knowledge...Education is the primary means of ensuring indigenous peoples' individual and collective development; it is a precondition for indigenous peoples' ability to realize their right to self-determination, including their right to pursue their own economic, social and cultural development."EMRIP (2009: 4-5 and 25) in Champagne (2009) 
Education is a significant initiator of development at the individual, community, national and global levels. For individuals, education is a lifelong asset and one of the most economically sound investments an individual can make. On average, each additional year of schooling translates into a $10 \%$ increase in an individual's income and every average year of additional schooling translates into a $1 \%$ increase in a country's GDP.

\subsection{Education and Economic Development}

Education like so many other social institutions is two-faced, forward-looking and backward looking. Education in the older sense of the word is training in the arts, crafts and values of a tribe or a class or a society. Education has tremendous scope as an instrument of social and cultural change. One should bear in mind that through education not only knowledge is imparted, but skills, interests, attitudes, aspirations and values are developed, social and cultural progress is facilitated, and at the same time social and cultural level of the people is raised. Education brings cultural changes which may result in many transitions and alterations in the society in many forms. This may be observed in every aspects human culture like variations in norms of values and thinking modes, changes in material culture, ideas, family relations, political culture, patterns of administration at the local, state, regional and national level, involvement in social activities, change in abilities and attitudes of personnel; in short in every aspects of human activity.

In the words of Golda Meyer "The purpose of education is to civilize the thousands of barbarians that are born in to this world every hour". If education fails to bring change in the learner, then it is worthless. Education is considered the most powerful tool in bringing change in man. On one hand, education acculturates an individual; on the other hand, it preserves, transmits and develops the culture of a society. In short, education and culture are mutually interdependent, complementary and supplementary in all their aspects and activities. Thus the relation between education and culture is inseparable. (Basha, 2017)

Culture plays a vital role in man's life. Education of various elements of culture can help man in the adaptation to the natural and social environment, development of individual's personality, socialization of the individual, proper use of leisure, and understanding other cultures and proper meaning of liberality. Education in culture is imparted mainly by the family, society and the school. Considering the importance of culture in man's life and the role played by education in the socialization and acculturation of an individual, it is worthwhile to analyse the changes that have taken shape in our culture. Before embarking on the discussion on the impact of education on culture, let us briefly understand the concept of culture itself.

\section{MeTHOdOLOGY}

This study employed descriptive-correlational design using a survey questionnaire which was also interpreted in the Manobo Language.

This study employed a descriptive-correlational research design. There were 106 respondents, conveniently chosen by the researchers based on their accessibility in the different Manobo dominated areas in Cotabato Province. The research questionnaire was constructed by the researchers which passed through reliability and validity testing and was also interpreted in the Manobo language for easy understanding of the respondents. The data were treated using Correlation, Chi-square, and Contingency Coefficient. Descriptive statistics simply described the respondents' level of education, level of socio-cultural development, and the level of economic development. The correlation test determined the relationship between level of education, socio-cultural development and the economic development.

Proper protocol was observed by the researchers before the data were gathered. Letter of approval was sought from the office of the National Commission for the Indigenous People (NCIP)-North Cotabato Provincial Office and the Barangay Chairman (political leader) of the community and the "Datu" (tribal leader) in the community. As part of the ethical standards of research, an informed consent was also sought from the respondents. Since there are those who have difficulty in writing, thumb printing was made instead of writing their names. The researchers also made ocular visit to the households during the conduct of the study in order to check on the sanitation, garbage disposal, household possessions, landholdings, vehicles, farm tools owned and farm animals raised and interviewed some "datus" (tribal leaders) that helped validate the data gathered. 
Influence of Education on the Socio-Cultural and Economic Development among the Manobo of Cotabato, Philippines

\section{RESUlTS AND DISCUSSIONS}

\subsection{Level of Education of the Respondents}

The study revealed a moderate level of illiteracy among the Manobo which subsequently, deprived them the chance to know themselves and be open to ideas that will contribute to their personal and collective improvement. A sad fact to note that of the 100 Manobo barely one (1) could graduate from high school and college (Horfilla,et.al.,1996) However, their access in the Alternative Learning System (ALS) has helped the out of school youths and adult Manobo to learn the Basic Literacy. The introduction of books and other instructional materials gave them a fleeting look into the world beyond the mountains. At present, the opening of the schools and community learning centers gave the Manobo the opportunity for schooling which they never enjoyed before (Gonos, 2012).

On the other hand, there are also a good number of those who have graduated in college due to the scholarship grants given by the government and non-government organizations. Most Manobo youths have moved to urban areas seeking for opportunities for education and employment (Rivera, 2014).

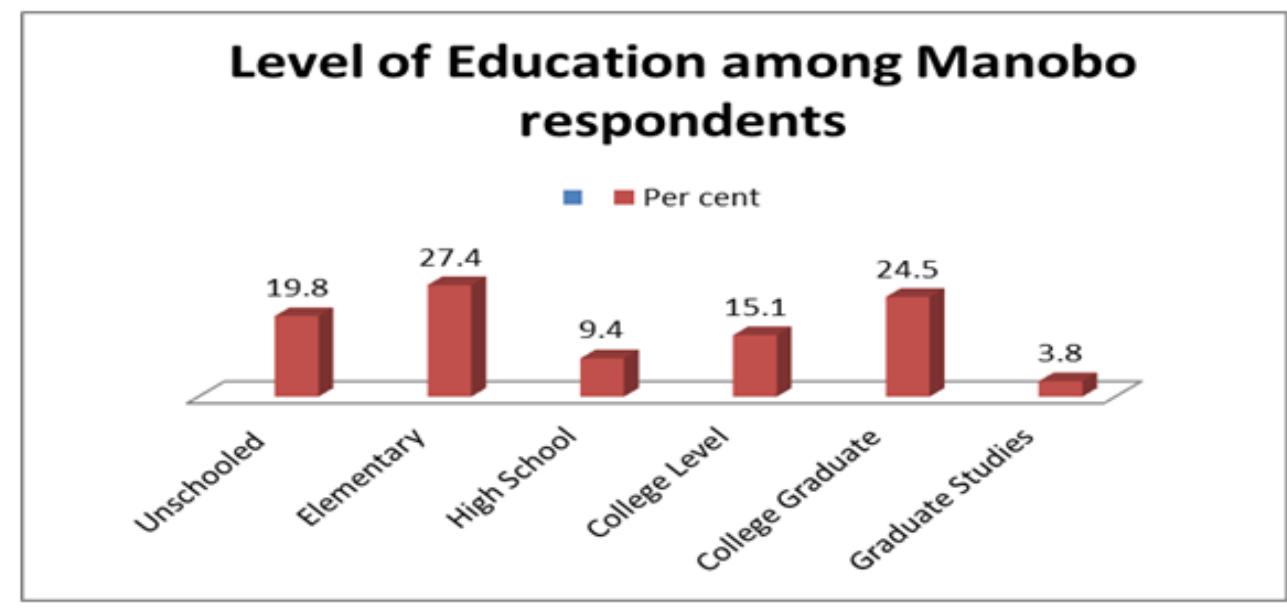

Fig2. Level of Education of the Respondents

\subsection{Socio-Cultural Development of the Respondents}

Only, a few of the Manobo respondents became leaders in the different organizations within the community although they actively participate in the different activities. In the past, Manobo society is usually led by a "Datu" (Tribal Chieftain) but with the introduction of the barangay system, the "Datus" were forced to adopt lowland forms of political government (Horfilla,et.al,1996).In addition, the structure of leadership at present is gradually changing with an overlay of the contemporary civil structures radiating from the governor of the province down to the level of the sitio councilman often assumed by the better educated younger generation of the community (National Commission for Culture and Arts, 2015).

Table. 1 shows that education has significant and positive relationship with socio-cultural development factors in terms of leadership, community involvement, tending sick, sanitation, garbage disposal, child care and immune system,

Table1. Relationship between education and socio-cultural Development of the Manobo

\begin{tabular}{|l|l|l|l|l|l|l|l|l|}
\hline Variables & 1 & 2 & 3 & 4 & 5 & 6 & 7 & 8 \\
\hline 1.Education & 1 & & & & & & & \\
\hline 2.Leadership & $.395^{* *}$ & 1 & & & & & & \\
\hline 3.CommunityInvolvement & $.271^{*}$ & .719 & 1 & & & & & \\
\hline 4.Tending Sick & $.474^{* *}$ & $.231^{*}$ & $.257^{* *}$ & 1 & & & & \\
\hline 5.Sanitation & $.567^{* *}$ & $.323^{* *}$ & $.215^{*}$ & $.606^{* *}$ & 1 & & & \\
\hline 6.Garbage Disposal & $.610^{* *}$ & $.316^{* *}$ & $.262^{* *}$ & $.651^{* *}$ & $.671^{* *}$ & 1 & & \\
\hline 7.Child care & $.557^{* *}$ & .175 & .058 & $.500^{* *}$ & $.641^{* *}$ & $.671^{* *}$ & 1 & \\
\hline 8.Immune System & $.493^{* *}$ & $.202^{* *}$ & .147 & $.444^{* *}$ & $.418^{* *}$ & $.615^{* *}$ & $.569^{* *}$ & 1 \\
\hline
\end{tabular}

Legend: **.01 level of significance- 2 tailed

*.05 level of significance- 2 tailed 
Likewise, most Manobo respondents have already adopted the proper health practices such as tending the sick, sanitation, garbage disposal, delivery and child care and the immunization of their children. The seminars and trainings given by the health personnel in the community made them become aware of the proper health practices. The presence of the barangay health centers gave the respondents the chance to see the doctors and health officials for checkup. Culturally, animism is the mainspring of the tribal religion and animal sacrifices are required to appease the offended spirit in times of illness (Peralta,2013). Manobo cultural practices are still rich and authentic however, the interaction and observation of the Manobo regarding the practices of other migrant settlers in every community gradually replaced some of their cultural practices. As much as they want to preserve their culture, most of the Manobo have already accepted the fact that the future generations will be civilized by the posing migrants crashing to their system (Masendo, 2015). Equally important to them now, is the recording and documentation of their cultural practices for preservation.

\subsection{Socio-Economic Development of the Respondents}

Farming is the major livelihood of the Manobo (Alejo, 2012) but unfortunately, their farming methods are still primitive. Agriculturally, they still practice the slash-and-burn farming (Peralta, 2013). They usually own 2-3 farming tools. Some of them are now engaged in secondary activities to augment their income. Most Manobo owned an average of 1-2 hectares of land which they inherited from their ancestors (Gaspar, 2010). Their average income per month ranges from P5, 000-10,000 (US\$100200). Since most of them are struggling for their daily survival, only those who have the capacity to fund the farming system can maximize the use of their lands to make it productive. But for those respondents who have no big amount of money and have not upgraded their skills in advance farming, they left their farm lots unproductive that pushed them to sell portions of these lands (Horfilla et.al, 1996).Indigenous Peoples are five percent of the world population but they also represent 15 percent of the world's poor (Shahani,2015).

Table. 2 reveals positive influence of education on the economic development among the Manobo in terms of family income, house hold properties, cars and farm animals.

Table2. Relationship between education and the socio-economic development of the respondents

\begin{tabular}{|l|l|l|l|l|l|l|l|l|}
\hline & 1 & 2 & 3 & 4 & 5 & 6 & 7 & 8 \\
\hline 1. Education & 1.00 & & & & & & & \\
\hline 2. Family income & $.677^{* *}$ & 1.00 & & & & & & \\
\hline 3. Employment & -.285 & -.271 & 1.00 & & & & & \\
\hline 4. Years Employed & .053 & .238 & $-.502^{* *}$ & 1.00 & & & & \\
\hline 5. HH prosessions & $.413^{* *}$ & $.593^{* *}$ & -.089 & .294 & 1.00 & & & \\
\hline 6. Land holdings & .135 & $.431^{* *}$ & -.100 & $.324^{*}$ & $.562^{* *}$ & 1.00 & & \\
\hline 7. Cars & $.401^{* *}$ & $.652^{* *}$ & -.149 & .102 & $.598^{* *}$ & $.462^{* *}$ & 1.00 & \\
\hline 8. Farm animals & $.193^{*}$ & $.291^{* *}$ & -.150 & .210 & $.472^{* *}$ & $.288^{* *}$ & $.388^{* *}$ & 1.00 \\
\hline
\end{tabular}

With the opening of the schools and roads, the Manobo people have the chance to be exposed to the outside world. The Manobo felt the need for education so they could improve their status in life. On the socio-cultural practices, the findings revealed that some of their socio-cultural practices were already replaced by adapting some of the practices of the migrant settlers, however, those sociocultural practices need to be improved in today's setting for faster healing of the sick, having clean surrounding will help the respondents get rid of bacteria and virus exposure, the implementation of the proper garbage disposal which is turned into a law and an advocacy of the barangay and the health policy of the government for the proper and healthy delivery of children and tending the sick.

\section{CONCLUSIONS}

The social interaction of the Manobo with the other migrant settlers has influenced their way of thinking and their way of living confirming the sociocultural theory of human learning of Vygotsky.

The lack of funds for livelihood and the primitive method of farming were still the issues among the Manobo people.

The basic community services like health, education and others were already enjoyed by the respondents that also gradually replaced their cultural system. 
Influence of Education on the Socio-Cultural and Economic Development among the Manobo of Cotabato, Philippines

The positive influence of education on the socio-cultural and economic development of the Manobo has helped them improve their standards of living.

\section{RECOMMENDATIONS}

The Government, Non-Government and other interested organizations should continue to strengthen their services on the educational and livelihood programs among the Manobo through trainings and seminars for their awareness and productivity.

The government should play an active role in organizing skills training in advance farming and provide funds for the livelihood of the Manobo for the preservation of their lands.

The Commission Higher Education (CHEd) together with the other concerned agencies may put up an Institute for Indigenous Studies in Cotabato for the preservation of the Indigenous Peoples' culture that will offer a culturally appropriate and rights-based educational curriculum.

\section{TRANSLATIONAL RESEARCH}

The result of the study could be translated through a journal article for international publications, social media, and other media for information dissemination and to strengthen the government programs for the Indigenous People.

Additionally, government, non-government agencies and other interested funding agencies may be encouraged to translate it into a more comprehensive intervention program that could help address the concerns of the education sector. Finally, it can be translated by sharing this research with the Manobo Youth for them to hope for a better future.

\section{ACKNOWLEDGEMENT}

With sincere appreciation and gratitude, the researchers would like to thank the Notre Dame University, CMC administration, Fr. Albert Alejo,S.J of Mindanaon, Ateneo de Davao University, Mount Apo Foundation Incorporated (MAFI), the different Manobo Tribal Leaders of Cotabato and the researchers family and friends.

\section{REFERENCES}

[1] Abayao, Leah E., (2014) The Philippines Indigenous Peoples' Core Curriculum, UP Forum, date retrieved: June 16, 2016 http://web-old.up.edu.ph/the-philippines-indigenous-peoples-core-curriculum/

[2] ABS-CBN (2015). Indigenous-peoples-in-philippines-decry-continuing-discrimination retrieved on August 6, 2017 from http://news.abs-cbn.com/focus/12/25/15/

[3] Abejuela, R. I. (2007). Indigenous knowledge systems and higher education in the Philippines, KRE journals online, date retrieved: June 16, 2016, http://www.krepublishers.com/06-Special\%20VolumeJournal/S-T\%20\&\%20T-00-Special\%20Volumes/T\%20\&\%20T-SV-01-Africa-Web/T\%20\&\%20T-SV01-19-205-07-Abejuela-R/T\%20\&\%20T-SI-19-205-07-Abejuela-R-Ab.pdf

[4] Alejo, Albert, SJ, PhD. (2000)-Generating energies in Mt. Apo- Cultural politics in a contested environment, Ateneo De Manila Press, date retrieved: June 16, 2016, http://www.ateneo.edu/ ateneopress/product/generating-energies-mount-apo-culturalpolitics-contested-environment-print

[5] Asia Indigenous Peoples’ Pact (AIPP, 2007) conference, Pokhara, Nepal, Date retrieved: August29, 2017, https://aippnet.org/publication/aipp-annual-reports/

[6] Chand Basha.P. (2017), Role of education in social change, International Journal of Advanced Educational Research, Volume 2; Issue 5; 236-240.

[7] Champagne, D. (2009), Contemporary Education in State of the World's Indigenous Peoples, Ch. IV. UN Department of Economic and Social Affairs, ST/ESA/328.

[8] Department of Education, (2010).The alternative learning system (ALS) curriculum for Indigenous Peoples (IPs) education. In: DepEd Order No. 101 s 2010, date retrieved: August 18, 2016, http://www. deped.gov.ph/2010/09/14/do-101-s-2010-the-alternative-learning-system-als-curriculum-for-indigenouspeoples-ips-education/

[9] Department of Education, (201I).Adopting the National Indigenous peoples (IP) Education Policy Framework, DepEd Order 62, S. 2011, date retrieved August 18, 2016, from http://www.deped.gov. ph/2011/08/08/do-62-s-2011-adopting-the-national-indigenous-peoples-ip-education-policy-framework/ 
Influence of Education on the Socio-Cultural and Economic Development among the Manobo of Cotabato, Philippines

[10] EMRIP (2009), Study on lessons learned and challenges to achieve the implementation of the right of indigenous peoples to education: Report of the Expert Mechanism on the Rights of Indigenous Peoples. Human Rights Council, UNGA, A/HRC/EMRIP/2009/2

[11] Elevaso Aurelio (1995), Philosophy of Philippine education, National Bookstore, 1995

[12] Gaspar, Karl, C.S.S.R. (2000) The Lumad's Struggle in the Face of Globalization.

[13] Davao City / Alternate Forum for Research in Mindanao / 2000 date retrieved: July 18, 2016, http://www.worldcat.org/title/lumads-struggle-inthefaceofglobalization/oclc/646392147/editions ?referer= di\&editions?View=true

[14] Gonos, Norma M. (2012). A response to the IPs clamor for holistic education of their children and youth, Journal of AghamTao, Ugnayang Pang-Aghamtao, Inc., Anthropological Association of the Philippines, Commonwealth, Avenue, Diliman, Quezon City.

[15] Hanusek, H.A. and L. Woessman (2010) The Economics of International Differences in Educational Achievement. National Bureau of Economic Research, Working Paper 15949. http://www.nber.org/ papers/w15949 (last accessed 30/09/2013).

[16] Horfilla,N.et.al., (1996) Arakan: Where the rivers speak of the Manobos living dreams, Davao City, Kaliwat Theater Collective Philippines http://results.mu.ac.in/myweb_test/MA\%20 Education-Sociology/ Chapter-6.pdf

[17] Indigenous Peoples Rights Act, (IPRA) 1997, Republic Act No. 8371 https://www.doe.gov. ph/sites/default/files/pdf/ocsp/ra_8371.pdf

[18] Masendo, Abraham L. (2015), The Manobo Then and Now: An Ethnography, International Journal of Scientific \& Engineering Research, Volume 6, Issue 4, April-2015, date retrieved: July 27, 2016, https://www.ijser.org/paper/The-Manobo-Tribe-Then-and-Now-An-Ethnography. html

[19] McLeod,S. A. (2014). Lev Vygotsky. Retrieved from www.simplypsychology.org/vygotsky.html

[20] NCIP (2013) Indigenous peoples of the Philippines. National Commission on Indigenous Peoples. Retrieved May 03, 2016, from http://www.ncip.gov.ph/indigenous-peoples-of-the-philippines.html

[21] National Commission for Culture and Arts brochure, 2015, date retrieved: August 16, 2016, http://ncca.gov.ph/publications/

[22] Peralta, Jesus T. (2003) Glimpses: Peoples of the Philippines, Anvil Pub., 2003

[23] Philippine Constitution 1987, https://www.lawphil.net/consti/cons1987.html

[24] Rivera, Karen (2014), A Manobo's journey: From mountains to high seas, date retrieved: August 16, 2016, https:/www.rappler.com/move-ph/issues/education/65195-manobo-journey-education

[25] Shahani, Lila (2015) Manobo youth in crisis, date retrieved: August 16, 2016, https://www.philstar. com/columns/133911/conjugations

[26] United Nations Human Rights (2009) Standing its ground: an indigenous community in the Philippines, date retrieved: August 16, 2016, https://www.ohchr.org/EN/NEWSEVENTS/ Pages/Standingitsgroundan IPPhilippines.aspx

[27] United Nations Development Report (2010). Indigenous Peoples in the Philippines, United Nations Development Program, Fact facts. Retrieved on August 16, 2017 from \%2520Indigenous\%2520Peoples \%2520in\%2520the\%2520Philippines\%2520rev\%25201.5.pdf

[28] Vygotsky's Socio-Cultural Theory, date retrieved: August 16, 2016, http://www.ceebl.manchester.ac.uk/ events/archive/aligningcollaborativelearning/Vygotsky.pdfwww.instructionaldesign.com

[29] Vygotsky, L. S. (1978). Mind in society: The development of higher psychological processes. Cambridge, MA: Harvard University Press. 


\section{AUTHORS' BIOGRAPHY}

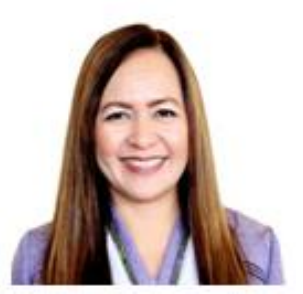

Dr. Beatriz De Villa- Gosadan, is a graduate of Doctor of Education at Notre Dame University. She is currently employed at Central Mindanao Colleges as teacher and Vice President for Institutional Services \& Academic affairs. She is a peer reviewer, editor, social research practitioner. She has also published articles in National and International researcher journals in the topics on Indigenous People, Women Issues and Education.

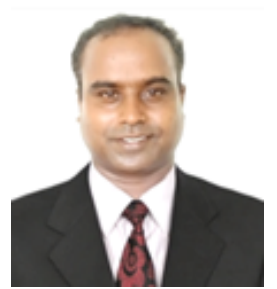

Bro. Dr. Arul Rayan, FSG is the member of Montfort Brothers of St. Gabriel. He holds BE, MBA and Ph.D. from University of San Agustin, Iloilo City, Philippines. He is a member of National Research Council of the Philippines and a certified Peer reviewer in International Research Journals in Asia, Africa, and America. He has published research papers in Organizational behavior and Technical vocational education and training.

Citation: Beatriz De Villa-Gosadan, Bro. Arul Rayan. "Influence of Education on the Socio-Cultural and Economic Development among the Manobo of Cotabato, Philippines. "International Journal of Humanities Social Sciences and Education (IJHSSE), vol 5, no. 8, 2018, pp. 193-202. http://dx.doi.org/10.20431/23490381.0508018

Copyright: (C) 2018 Authors. This is an open-access article distributed under the terms of the Creative Commons Attribution License, which permits unrestricted use, distribution, and reproduction in any medium, provided the original author and source are credited. 